\title{
Web-Based Learning Implementation to Improve Students' Learning Outcomes on Understand Evaluating the Public Policies' Impact Material during the Covid-19 Pandemic
}

\author{
Evi Susilawati ${ }^{*}$, Imamul Khaira² \\ ${ }^{1}$ Faculty of Education Teaching and Training, Universitas Islam Sumatera Utara \\ ${ }^{2}$ Faculty of Social Humaniora and Education, Universitas Haji Sumatera Utara
}

*Corresponding author:

E-mail:

evisusilawati@fkip.uisu.ac.id

\begin{abstract}
The Covid-19 Pandemic (CoronaVirus Disease-19) caused the Government of the Republic of Indonesia to implement various policies to tackle the spread of Covid-19 so that those policies' impacts need to be evaluated. This activity of learning to topic evaluate the impact of public policies during the Covid-19 pandemic was carried out in the Public Policy course. This research activity uses a web-based learning strategy. Based on these web-based learning activities, this study aims: (1) to see web-based learning applications on the evaluation material for the impact of public policies during Covid-19, and (2) to see the increase in students' abilities in understanding the material for evaluating the impact of public policies during the Covid-19 pandemic. This research is Classroom Action Research (CAR). The research subjects subject to action were students of semester VII of the Pancasila and Civic Education study program, Faculty of Teacher Training and Education of the Islamic University of North Sumatra in the 2020/2021 academic year. The data analysis in this study used qualitative and quantitative descriptive techniques. The validity of the data in this study was carried out using observation sheets and student learning achievements tests on the evaluation material for the impact of Public Policy during the Covid-19 pandemic. The results of this study indicate that there is an increase in the learning outcomes of students to understand the material for evaluating the impact of public policies during the Covid-19 pandemic using web-based learning.
\end{abstract}

Keywords: Web-based learning, evaluating the public policies' material during the covid-19 pandemic

\section{Introduction}

The Covid-19 pandemic, which has spread globally throughout the world since 2019 , is currently at an alarming stage. With the scale of transmission of the spread being so high and fast, the Government of the Republic of Indonesia, through Presidential Decree No. 12 of 2020 officially announced that the Covid-19 virus had become a national disaster and had even shown the number of Covid-19 spread of 3.409.658 cases in Juli 2021 (Nurhakim, 2020).

The massive spread of the Covid-19 virus has affected many sectors, so a strong political decision is needed. Therefore, an effective policy instrument is needed to deal with and reduce cases of the Covid-19 virus. The Indonesian government responses, through the President of the Republic of Indonesia, issued 9 (nine) legal products that became the reference for the policy for handling Covid-19. The nine instruments are 1 (one) Government Regulation in Lieu of Law (Perppu), 1 (one) Government Regulation (PP), 1 (one) 100 Presidential Instructions (Inpres), 2 (two) Presidential Regulations (Perpres), and 4 (four) Presidential Decrees (Keppres). All of these policy in-

Krishanti, N. P. R. A., Zulfiana, D., \& Wikantyoso, B. (2020). Web-based learning implementation to improve students' learning outcomes on understand evaluating the public policies' impact material during the covid-19 pandemic. $1^{\text {st }}$ Education Research and Applied Business Conference. NST Proceedings. pages 95-102. doi: 10.11594/ nstp.2021.1113 
struments are intended to respond to the escalation of problems caused by the pandemic in different aspects, both in aspects of public health in general, government administration, finance, and politics, and strengthening the authority of the government bureaucracy. Such legal products refer to Law No. 6 of 2018 concerning Health Quarantine (Health Quarantine Law) which contains several policy options that can be taken by the central and local governments in dealing with the Covid-19 pandemic. Of the nine policies, the focus of the discussion of this article is on the policy of Large-Scale Social Restrictions (PSBB) contained in PP No. 21 of 2020 concerning Large-Scale Social Restrictions in the context of Accelerating the Handling of the spread of Covid-19.

The policies above need to be evaluated for their impact, especially on the level of effectiveness. The activity of evaluating the impact of this public activity is contained in the Public Policy course. This course is held at the Faculty of Education and Teaching Training at the Islamic University of North Sumatra, the Pancasila and Civic Education study program for students in the seventh semester as many as 2 (two) semester credit units. Students' understanding of the material for evaluating the impact of public policies during the Covid-19 pandemic is very important. This is based on the fact that until 2021 various efforts have been made by the Government of the Republic of Indonesia to suppress the increase in virus infections and reduce the risk of the spread of Covid-19 both through curative and preventive measures, so far, no satisfactory results have been seen. On the other hand, in several reports, the Government of the Republic of Indonesia has been listed as one of the countries with the highest categorization of Covid-19 morbidity and mortality in the world. A report by Forbes magazine entitled 'Deep Analysis of Global Pandemic Data Reveals Important Insight' which analyzed in the form of rankings for handling Covid-19 around the world has placed Indonesia in the high-risk category (Collangelo, 2020). The report at least illustrates that the handling carried out by the central government and local governments, especially in terms of handling in health facilities and government management in general, is still quite low and far from global handling standards.

Currently, the problem with the ineffectiveness of handling this pandemic is the difference in policy steps between the central and local governments. There are coordination problems, especially at the local level where there is no clear authority in handling Covid-19 even though the central government has provided several policy options previously. This causes many local heads to tend to take policies that vary and differ from one another. This condition then makes the resulting impact also different and even far from what was expected. Many decisions taken by local heads are controversial. In response to the controversial decisions taken by local heads, researchers have researched the handling of the Covid-19 pandemic to help the government suppress the rate of spread at the national and local levels. The research from Dzakwan (2020) which contains an evaluation of the government's centralization policy in handling Covid-19 shows that the government's efforts in handling Covid-19 centrally are the cause of the problem of ineffective handling. The research also tries to measure the readiness of several regions, especially in terms of health service capacity. Furthermore, based on research by Juaningsih (2020), it is confirmed that the guarantee for welfare and security for the community has been carried out by the government, namely through the PSBB policy mandated by the Health Quarantine Law. The study found that the handling of Covid-19 was not very effective because people did not fully understand the urgency of the health emergency. Institutional efforts in the form of socialization, according to the research recommendations, must be intensively carried out to increase awareness of the dangers of Covid-19. The main problems in handling the Covid-19 pandemic which illustrates that the leading factor in handling pandemics or crisis management for regional heads, is not always a determinant of success in suppressing the level of spread in the area.

Teaching and learning process on the material impact evaluation of public policy in Faculty of Education and Teaching Training, Universitas Islam Sumatera Utara (UISU) study program Pancasila and Civic Education was done using web-based learning. Web-based learning carried out at UISU is following the Long-Term Plan (RJP) and UISU Statutes to become a university that has 
academic excellence and becomes a barometer of scientific progress that can compete at the global level (Susilawati \& Khaira, 2021). This web-based learning is an alternative learning activity during the Covid-19 Pandemic that can use various tools and learning methods and can encourage the development of various student skills in creating effective learning. (Susilawati \& Khaira, 2021).

This web-based learning does not reduce the meaning in the learning process where lecturers can provide information for student learning activities using e-learning so that students can absorb the information provided by the lecturer (Susilawati, 2020). E-learning is defined as learning that uses multimedia and internet technology to improve the quality of learning by facilitating access to facilities and services as well as remote exchange and collaboration (Nasirun et al., 2021). Based on research by Klein and Ware, (2003) explained that the use of learning using elearning provides the following benefits: (1) the use of e-learning is easy and practical; (2) has built the ability of students to focus on student needs for the delivery of knowledge, (3) flexible in the use of time and place, (4) can increase the effectiveness of knowledge and material qualifications through easy access to large information, (5) able to provide opportunities for students to discuss anytime and anywhere, (6) able to help remove barriers that have the potential to hinder participation including the fear of talking to other students, (7) e-learning motivates students to interact with other people, as well as exchange and respect viewpoints different.

\section{Material and Methods \\ Research methodology}

This research using Classroom Action Research (CAR). CAR is one type of research that has a systematic approach to finding solutions to problem-solving in the classroom (Ekasari, 2021). This Research conduct on the Faculty of Education and Teaching Training Universitas Islam Sumatera Utara, Study Program Pancasila, and Civic Education. Research subjects in this research are all seventh-semester students who are taking Public Policy courses in the 2020.2 academic years (10 Students). This learning improvement research was carried out from the initial observation of learning until the completion of the third cycle.

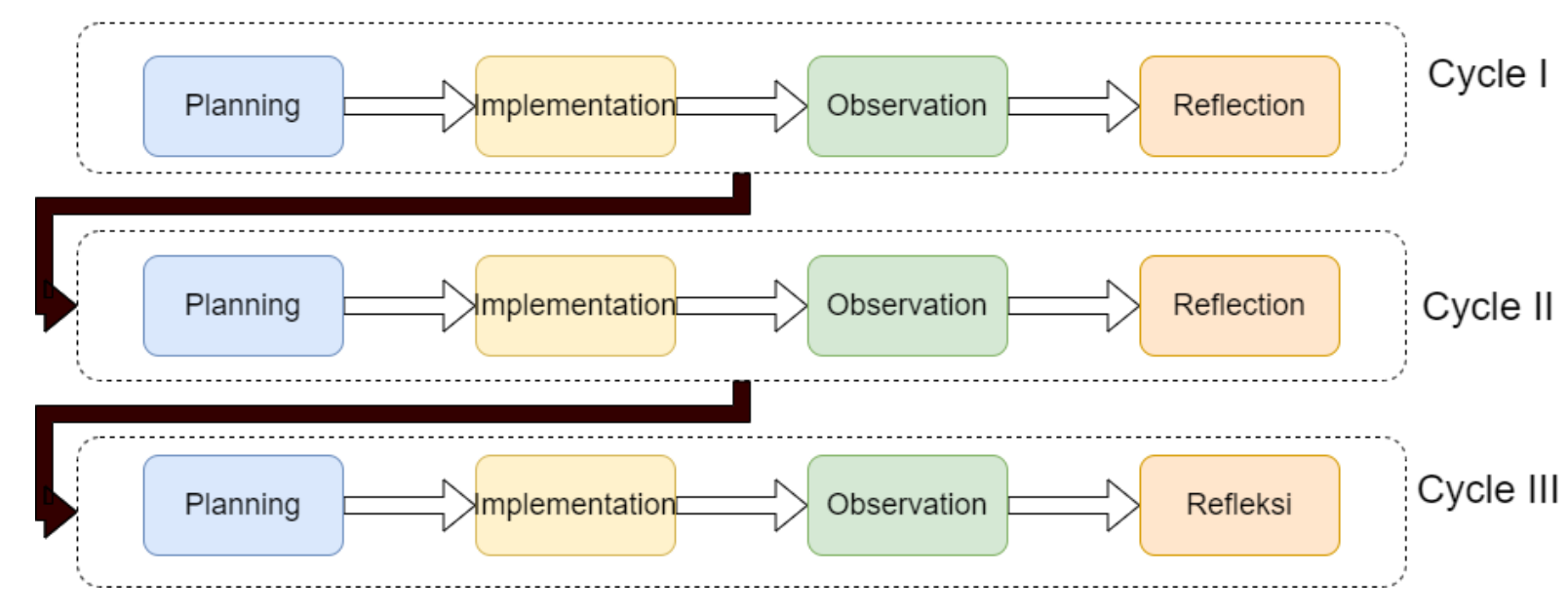

Figure 1. CAR cycle of web-based learning application

Figure 1 showed that the implementation of CAR begins with conducting a preliminary study. Preliminary study activity by asking colleagues to observe the learning process of the Public Policy course. The data of this research are in the form of observations, and student learning outcomes from each improvement in the learning of the Public Policy course studied. This data is about matters related to the planning, implementation, and learning outcomes of Public Policy courses. This 
CAR is carried out in 3 (three) cycles with 4 (four) stages namely: (1) Planning, (2) Implementation, (3) Observation, and (4) Reflection. Design of CAR with 3 cycles.

The explanation step of CAR is explained as below:

\section{Planning}

(a) plan the material for evaluating the impact of public policies by visit https://elearning.uisu.ac.id

(b) create a semester lesson plan,

(c) develop web-based learning media and upload to https://elearning.uisu.ac.id

(d) prepare the necessary resources, materials, and tools,

(e) create a web-based learning observation format, namely the lecturer observation format and the student observation format

(f) Prepare evaluation questions for learning outcomes for evaluating the impact of public policies and answer keys.

\section{Implementation}

Implementation of CAR on web-based learning application material for evaluating the impact of public policies with zoom meeting. This web-based learning application activity follows the following learning steps:

(1) Preliminary Activities with the following activities:

a) Invite students to pray

b) List student attendance

c) Relate matter to the state of things that are happening,

d) Increase student attention,

e) Convey learning objectives,

f) Encourage students' recollection of information about the material they have learned at the previous meeting.

(2) Core Activities with the following activities:

a) Invites students to look at one of the videos that are following the material for evaluating the impact of public policies during the Covid-19 pandemic at portal https://elearning.uisu.ac.id,

b) Providing stimulus to students about learning activities and various impacts of public policies during the Covid-19 pandemic issued by the government as well as various research results on the impact of evaluating public policies,

c) Ask students to discuss it in groups,

d) Ask student representatives to present them,

e) The lecturer responds to the results of student presentations and gives awards with the best participation scores for students who present their work well,

f) The lecturer invites students to read the material on the worksheet at the link https://elearning.uisu.ac.id,

g) Guide students' understanding of the impact of evaluating public policies during the Covid-19 Pandemic.

(3) Closing Activities with the following activities:

a) Provide informative feedback to students,

b) provide a test of learning outcomes on the impact of public policy evaluation materials, and,

c) Retention and transfer of learning through assignments. 


\section{Observation}

The observation stage of web-based learning applications on material impact of public policy evaluation and interpretation is carried out simultaneously with the implementation of corrective actions. At this stage, the researcher conducts discussions with colleagues based on the results obtained at the observation stage to review whether the learning activities are following the learning steps that have been set.

\section{Reflection}

At this stage, the researcher looks for deficiencies in the learning process and makes improvements to the semester learning plan to be used in the next cycle.

\section{Material and analysis data}

Data analysis in this research uses qualitative and quantitative descriptive analysis. This qualitative descriptive analysis in CAR provides an explanation of student activities and the ability of lecturers during the learning process of material impact of evaluating public policy. Furthermore, quantitative descriptive analysis is used on the activities of lecturers in managing learning, the percentage of student activities, and the percentage of learning outcomes on the impact of public policy evaluation. This research instrument consists of three, namely: (a) Lecturer observation sheets used to obtain data on lecturers' activities in managing learning on the impact of public policy evaluation materials, (b) Student participation observation sheets during the learning process, and (c) Tests student learning outcomes are carried out at the end of each cycle

The implementation of CAR is considered successful if it has met the indicators for the success of the action, namely: (1) learning process on the impact of public policy evaluation material if this CAR obtains: (a) The average student participation score is 80 (b) Average the average activity of lecturers has obtained a minimum score of 80. (2) learning outcomes on the impact of public policy evaluation materials, individually if student learning outcomes have reached a value of 80 .

\section{Results and Discussion}

\section{Results of observations on student learning participation on the impact of public policy eval- uation during the covid-19 pandemic}

Data regarding the results of student participants who took part in the impact of evaluating public policy during the Covid-19 pandemic on seventh-semester students at the Faculty of Education and Teaching Training of the Islamic University of North Sumatra during the learning process through a Web-Based Learning Application by using an observation sheet on student learning participation in the cycle. I obtained an average score of 52.60, in the second cycle an average score of 73.40, and in the third cycle an average score of 81.30. The achievement of student participation scores in the third cycle has reached an indicator of success in this study.

Table I. Observation results of student learning participation

Cycle Average Score
Cycle 1
52,60
Cycle 2
73,40
Cycle 3
81,30 
Results of observations on observations of lecturers' teaching activities on the impact of public policy evaluation during the covid-19 pandemic

Observations of lecturers' teaching activities on the evaluation of the impact of public policies during the Covid-19 pandemic through a Web-Based Learning Application using observation sheets obtained data in the first cycle showing an average score of 51.00, in the first second cycle it shows the average score 73,20, and in the third cycle, the average score is 84.5 . In this third cycle, the lecturer's activities have reached the indicators so that this research is stopped.

Table 2. Observation results of teaching lecturer activities

Cycle Average Score

Cycle 1

Cycle 2

Cycle 3
51,00

73,20

84,50

Improving learning outcomes with web-based learning applications on the impact of public policy evaluation during the covid-19 pandemic

Web-Based Learning Application supports learning process on material for evaluating the impact of public policies in the middle pandemic Covid-19. After applied web-based learning application in 3 cycles, Then the student learning outcomes test is carried out shown in Figure 2.

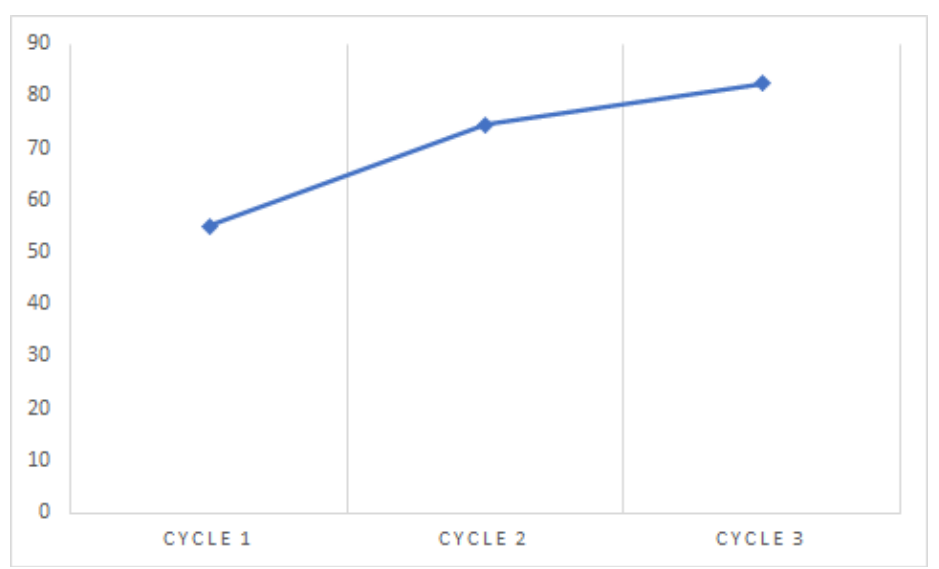

Figure 2. Increased average learning outcomes

The Public Policy course using Web-Based Learning Application in Figure II, cycle I show that students' understanding of the material taught is still relatively low because it does not obtain the criteria of 70.0 with an average score of 55.10, while in the second cycle it is obtained the average value is 74.50 , and at the third meeting the average score is 82.40 . The achievement of the criteria for obtaining student learning outcomes on the impact of evaluating public policy during the Covid-19 pandemic using this Web-Based Learning Application, this research was stopped or not continued in the next cycle.

\section{Discussion}

After the implementation of web-based learning to evaluate the impact of public policy during the Covid-19 pandemic, there has been an increase in student learning activities. It is realized that 
the material for evaluating the impact of public policy is material that is difficult for students to understand from all the material contained in the Public Policy course. The use of web-based learning applications can increase student learning participation in understanding the impact evaluation material of public policies during the Covid-19 pandemic because the use of e-learning can help students understand the material that is difficult to understand and too much material.

Web-based learning applications are also able to increase lecturers' teaching activities in evaluating the impact of public policy during the Covid-19 pandemic. As explained above, the material for evaluating the impact of public policies during the Covid-19 pandemic is material that is difficult for students to understand because lecturers must be able to display and represent various public policies related to the Covid-19 pandemic that the government has made and evaluate with students about the impact of the COVID-19 pandemic. policies that have been made. Lecturers must also be able to present various current research results related to evaluating the impact of policies during the Covid-19 pandemic. Based on the difficulties in presenting the material, the use of web applications in this learning activity has made it easier for lecturers to deliver material on evaluating the impact of public policies during the Covid-19 pandemic. This is based on the use of e-learning based on the adoption of e-learning technology in online classes that are easy and practical and can increase the effectiveness of knowledge and material qualifications through easy access to large amounts of information.

The use of web-based learning applications has improved student learning outcomes in evaluating the impact of public policy during the Covid-19 pandemic. This is because web-based learning provides a set of tools that can enrich the value of student learning in understanding the impact evaluation material of public policies during the Covid-19 pandemic so that students can have enriched material content and search for material more broadly and flexibly. Through the use of web-based learning applications, students can identify, recognize, and make their own decisions regarding their planned learning progress. Referring to the advantages possessed by this webbased learning application, of course, it can improve student learning outcomes in evaluating the impact of public policy during the Covid-19 pandemic.

\section{Conclusion}

Implementation Web-Based Learning Application on material for evaluating the impact of public policies in Public Policy Courses, Study Program Pancasila and Civic Education, Faculty of Education and Teaching Training Universitas Islam Sumatera Utara during Covid-19 Pandemic showed an effective increase in students learning outcomes. Web-based Learning Application on material for evaluating the impact of public policies in Public Policy Courses the learning process during the Covid 19 pandemic also shows an effective increase in student teaching activities carried out by lecturers and student participation.

\section{References}

Collangelo, Margaretta. (2020). Deep analysis of global pandemic data reveals important insights. The $130^{\text {th }}$ Canton Fair online and offline. Forbes.com. (https://www.forbes.com/sites/cognitiveworld/2020/04/13/covid-19- complexity-demands-sophisticated-analytics-deep-analysis-of-global-pandemic-data-reveals-important-insights). Retrieved 24 Juli 2021.

Dzakwan, M. H. A. (2020). Memetakan kesiapan pemerintah daerah dalam menangani covid-19. Naskah CSIS Commentaries DMRU 027-1. (https://csis.or.id/publications/memetakan -kesiapan-pemerintah-daerah-dalam-menangani-covid-19). Retrieved 24 Juli 2021.

Ekasari, N. (2021). Penerapan metode circuit learning untuk meningkatkan hasil belajar siswa. Jurnal Pendidikan Indonesia, 2(2), 282293. https://doi.org/10.36418/japendi.v2i2.69

Juaningsih. (2020). Optimalisasi kebijakan pemerintah dalam penanganan covid-19 terhadap masyarakat Indonesia. Salam: Jurnal Sosial Budaya Syar'I, 7(6), 509-5018. Doi: https://doi.org/10.15408/sjsbs.v7i6.15363

Klein, D. \& Ware, M. (2003). E-learning: New opportunities in continuing professional development. Learned Publishing,16(1), 34-46.

Nasirun, M., Indrawati, \& Suprapti, A. (2021). Studi tingkat pemahaman guru PAUD dalam Penelitian Tindakan Kelas (PTK). Jurnal Ilmiah Potensia, 6(1), 26-36. 
Nurhakim, R. (2020). UPDATE: Bertambah 3.444, kini ada 194.109 kasus covid-19 di Indonesia. Kompas.com. ( https://nasional.kompas.com/read/2020/09/06/15514501/update- bertambah -3444-kini-ada-194109-kasus-covid-19-di-indonesia). Retrieved 25 July 2021.

Susilawati, E. (2020). Aplikasi tutorial berbantuan web untuk meningkatkan hasil belajar matakuliah pembelajaran PKn di SD Di Tengah Pandemi covid -19. E-Prosiding Seminar Nasional Virtual Pendidikan Kewarganegaraan 2020. Semarang: Universitas Sebelas Maret.

Susilawati, Evi \& Khaira, Imamul. (2021). Peningkatan kreativitas mahasiswa dalam merancang rencana pelaksanaan pembelajaran berbasis TPACK sebagai integrasi pembelajaran di era society 5.0. E-Prosiding Seminar Nasional Pendidikan Pancasila dan Kewarganegaraan 2021. Semarang: Universitas Sebelas Maret. 